\title{
Assessment of Public Perspectives on Quality Control Measures in Public Water Supply in Oyo state, Nigeria
}

\section{$*^{1}$ AMORI, AA; ${ }^{1}$ ODJEGBA, EE. ${ }^{2}$ ADEKITAN, AA $^{3}$}

\author{
Department of Water Resources Management and Agricultural Meteorology \\ College of Environmental Resources Management, Federal University of Agriculture, Abeokuta, \\ P.M.B 2240, Ogun State \\ 1drdeolaamori@yahoo.co.uk; ${ }^{3}$ abimbolaadetoun@yahoo.com
}

KEY WORDS: Quality Control, Public Water Supply, Water Use, Public Perception, Water Governance.

\begin{abstract}
The study determined whether there were differences in public evaluation and perception of quality control measures adopted by a public water agency in Oyo State, Nigeria on the basis of some socio-demographic factors such as age, gender, marital status and socio-economic background. It used a sample of 350 respondents (187 males and 163 females) spread across four local government areas in Oyo State. The major instrument used was a questionnaire while data analysis employed frequency counts and t-test statistics. Result showed that there were no significant differences in public perception of quality control measures adopted by the public water agency on the basis of the aforementioned factors. The result raises some fundamental issues that are connected with the quality of water supplied for public uses. It underscored the need to enhance a high quality in public water supply. The paper further went to proffer solutions on how to sustain safe water supply in Nigerian cities: @ JASEM
\end{abstract}

http://dx.doi.org/10.4314/jasem.v19i1.2

\section{Introduction}

The concern for regular and uninterrupted public water supply in developing countries has been on the increase in the last four decades. This is in response to the incidents of water scarcity evident in cities and towns in most developing countries especially in Africa, Asia and South America. In ensuring regular public water supply, there is the need to ensure that the water being supplied is safe and potable, that is, it must be of high quality. This brings to fore the issue of quality control in public water supply. This issue is very critical and germane to the task of ensuring steady and regular water supply. Not only must water be available in the right amount to meet the demand, also the water must be of high quality such that it is suitable for public consumption. Where the quality of water supplied is law it has negative consequences for public health and well-being (Nwakwoala 2011, Areola and Akintola (1977), Akintola and Areola 1980; Adah and Abok 2013; Nwakwoala and Mmom 2008; Rijisbermann 2006; Offodile 2006, Okeke and Uzoh 2009; Oyebande 2006; Oteze (2006) and Tijani (2006).

To ensure quality control, public water agencies in Nigeria have adopted some modern and current best practices which include the establishment of water laboratories where regular water quality tests can be carried out, the use of modern water treatment methods, regular maintenance of the water distribution network especially the water pipes inspection and surveillance of the water pipe network for the purpose of preventing and detecting water pipe vanderlisation and leakages. All these measures combined together help in ensuring that the quality of water supplied to the public is high and considered safe for public use.

Given the importance of quality control in public water supply, it is best that public water agencies should accord it high priority in the discharge of their regular services (Ajayi, et al, 2003; Ajayi (2006), Babatola 1997; Ezeigbo 2003; Akpoborie 1999; Goni (2006); Hanidu 1990; Akpor and Muchie 2011; Faniran 1983, 1987 and 1991; Ayoade 1975 and Gbadamosi 2012). It is their responsibility to ensure that quality control is enhanced in their production activities while the public must equally demand it as far as, service delivery is concerned. For this reason, it becomes necessary that public perception of quality control in public water supply should be examined, so as to have a picture of how it is rated by the public. Hence this study determined whether there are differences in the way the public perceived, viewed or rated quality control measures adopted by a public water agency in Oyo State of Nigeria. This 
will help shed light on the activities of the water agency as far as the regulation of quality control is concerned. Furthermore, it will shed more light on how the public views the adequacy or otherwise of the existing quality control measures adopted by the water agency. From there, appropriate recommendation can now be made on how the issue of quality control can receive more attention than it is currently, as a way of improving on any area or lapses arising from what obtains currently.

\section{STATEMENT OF PROBLEM}

Over the years, public water agencies in Nigeria have been faced with the challenge of ensuring constant water supply and need to improve on the quality of water supplied to the public. This has raised the issue of quality control in public water supply given the scarcity and spread of waterborne disease experienced in most Nigerian towns and cities in recent times.

Indeed, the issue of quality control is germane and fundamental in ensuring regular and prompt supply of public water if public health is to be guaranteed. This, however, is not the case as public water supply is still at its lowest ebb in several towns and cities. For this situation to be properly addressed there is an urgent need to visit the issue of quality control in public water supply. Hence, this study examined whether there are significant differences in the way public viewed or rated quality control in the supply of potable water in Oyo State on the basis of some socio-demographic variables such as gender, marital status, and socio-economic background.

Research Question: Is there a significant difference in the perception of the public on quality control measures adopted by a public water agency on the basis of some socio-demographic variables such as age, gender, marital status, and socio-economic background?

Methodology: Sample and Sampling Procedure: The study involved 350 respondents (187 male and 163 females) drawn from four local government areas in Oyo State. The respondents were selected using stratified random sampling on the basis of local governments, wards and places of residence. The instruments used were distributed on the basis of the sampling frame drawn for the study.
Instrument: The instrument used (was a questionnaire) that obtained information on public perception of quality control measures adopted by public water agencies. The questionnaire consisted of three sections. Section A measured the demographic characteristics of respondents. Section B consisted of 24 items which measured respondents knowledge of quality control used in public water supply and attitude towards quality control in public water supply. Section C was attitude scales consisting of 13 items rated on a five-point scale ranging from strongly agree, agree, uncertain, disagree and strongly disagree. Respondents were requested to tick which of the options that tallied with their level of agreement with the statements.

In other to ensure suitability and validity, an earlier draft of the questionnaire was given to four experts in the area of evaluation studies and water resources management for their comments. Their comments were taken into consideration and this led to the modification of four items. After this, the modified version was administered on the respondents.

Data Collection: The data collection exercise was undertaken by the researcher with the assistance of three trained research assistants. Questionnaire was administered on the respondents and was retrieved immediately they had been filled. The exercise lasted for three months.

Data Analysis: Analysis of the collected data involved the comparison of the means of responses from the respondents using the t-test statistic for independent samples. The significant level was set at 0.05. Analyses were computed with the use of the Statistical Package for the Social Sciences (SPSS) Software Version 15.0 for windows.

\section{RESULTS AND DISCUSSION}

The t-test statistic was used in analyzing the data since the variables under consideration, that is gender, marital status, and socio-economic background all exists in two groups for the purpose of comparing and determining whether there were significant differences in the perceptions expressed by respondents on the issue of quality control in public water supply in Oyo State, Nigeria. The results are presented in Tables 1, 2 and 3. 
Table 1: T-test Comparison of the Mean Perception of Respondents on Quality Control in Public Water Supply in Oyo State on the Basis of Gender

\begin{tabular}{|c|c|c|c|c|c|c|c|}
\hline Gender & $\begin{array}{l}\text { Sam } \\
\text { ple }\end{array}$ & Mean & $\begin{array}{l}\text { Standard } \\
\text { Deviation }\end{array}$ & $\mathrm{T}$ cal & T cri/obs & $\mathrm{P}$ value & Remarks \\
\hline Male & 187 & 28.8142 & 6.91061 & 1.323 & 1.96 & 0.187 & NS* \\
\hline Female & 163 & 30.0920 & 10.82738 & & & & \\
\hline
\end{tabular}

Not significant at $\mathrm{p}>0.05$

Table 2: T-test Comparison of the Mean Perception of Respondents on Quality Control in Public Water Supply in Oyo State on the Basis of Marital Status

\begin{tabular}{|c|c|c|c|c|c|c|c|}
\hline $\begin{array}{l}\text { Marital } \\
\text { Status }\end{array}$ & $\begin{array}{l}\text { Sam } \\
\text { ple }\end{array}$ & Mean & $\begin{array}{l}\text { Standard } \\
\text { Deviation }\end{array}$ & T cal & T cri/obs & $P$ value & Remarks \\
\hline Single & 172 & 29.6548 & 9.10615 & 0.480 & 1.96 & 0.632 & NS \\
\hline Married & 188 & 29.1910 & 8.88009 & & & & \\
\hline
\end{tabular}

Table 3: T-test Comparison of the Mean Perception of Respondents on Quality Control in Public Water Supply in Oyo State on the Basis of Socio-Economic Background

\begin{tabular}{llllllll}
\hline $\begin{array}{l}\text { Socio- } \\
\begin{array}{l}\text { Economic } \\
\text { Background }\end{array}\end{array}$ & Sample & Mean & $\begin{array}{l}\text { Standard } \\
\text { Deviation }\end{array}$ & T cal & T cri/obs & P value & Remarks \\
\hline Low & 178 & 28.7022 & 9.57434 & 1.525 & 1.96 & 0.128 & NS \\
High & 172 & 30.1726 & 8.26652 & & & & \\
\hline
\end{tabular}

Table 1 showed that respondents did not differ significantly in their perception of quality control in public water supply in Oyo State on the basis of gender. This is so, because the $t$ value calculated which is 1.323 is less than the $t$ value observed from the statistical tables which is 1.96. Similarly, the $p$ value of 0.632 is greater than the $p$ value set for the test which is 0.05 . Hence, it is not significant at 0.05 level. This implied that both male and female respondents viewed quality control in public water supply the same way.

Table 2 also showed that there was no significant difference in the way respondents perceived quality control in public water supply on the basis of marital status. This is evident by the calculated $t$ value of 0.48 which is less than the $\mathrm{t}$ value observed from the statistical tables which is 1.96 . By the same token, the $p$ value of 0.632 is greater than the $\mathrm{p}$ value set for the test which is 0.05 . Hence, it is clear that there is no significant difference in the perception of quality control in public water supply in Oyo State on the basis of marital status. This means that both single and married respondents perceived quality control in public water supply the same way.

As for socio-economic background, the scenario remains the same as shown by the result presented in table 3 . From the table, the $t$ calculated is 1.525 which is less than the $\mathrm{t}$ value observed from the statistical table which is 1.96 equally, the $\mathrm{p}$ value obtained is 0.128 which is greater than the $p$ value set for the test which is 0.05 . The implication of this result is that the respondents did not differ significantly in their view or perception of quality control in public water supply in Oyo State. In other words, it is clear that both rich and poor respondents do not see the issue of quality control in public water supply differently but generally agreed on it, irrespective of their socio-economic background.

In all, the above analyses have showed that respondents regardless of their socio-demographic attribute viewed quality control in public water supply in Oyo state the same way. They all agreed in their observations and ratings concerning public water use in the State. The implications of this result are discussed in the next session of this paper.

The study investigated whether there were significant differences in public perception of quality control in Oyo State on the basis of four socio-demographic variables such as gender, marital status and socio-economic background. Result showed that there were no significant differences in public perception of quality control on the basis of the four aforementioned variables.

The implications of this finding are that the public never differed or disagreed on the issue of quality control measures in public water supply on the basis of the aforementioned variables. That is to say, regardless of the socio-demographic attributes of respondents, they all perceived or viewed 
quality control measures the same way. The sum total of this is that they all agreed as to the relevance of quality control in public water supply. This result is not surprising if it acknowledged that quality control is very crucial to the provision of safe and potable water supply as it helps to guarantee sound public health and sustainable development which is very essential to developing countries.

In view of this fact, it is crucial at this juncture to put forward some suggestions necessary towards ensuring the easy adoption of current practices in quality control matters.

First, it is essential that public water agencies should aim at prioritizing quality control. This is because quality control is one of the essential instruments for enhancing the production of safe and potable water. For this reason it is best that water agencies should devote more resources especially funds, personnel and material towards entrenching better quality control measures as this will ensure the steady supply of safe water for public consumption. If quality control is to be fully established within the agencies, several resources ought to be made available. The major resources involved here include funds, materials and personnel which will combine together to ensure the entrenchment of current practices in quality control. Funds are required in acquiring latest technology in quality control including other materials such as chemicals and reagents needed in treating water. Personnel are equally required in manning the various procedures and operation in quality control. All these resources will have to be effectively combined to ensure that effective quality control measures are put in place such that the regular supply of potable water is guaranteed. In essence, it is mandatory that funds be made available regularly such that quality control is not compromised. Where funds are lacking or inadequate, the continuous provision of safe and potable water will be hampered or allows inadequate water to be supplied such that it may not meet the public demand for water. In this situation, incidents of water scarcity and irregular supply of water is common feature.

Secondly, materials needed for water treatments such as reagents, alum, fluoride, chlorine etc. must be supplied regularly to boost the process of quality control. Current realities show that most public water agencies lack the regular supply of these materials. Hence, water produced by the agencies is often lacking the required quality and may be unsuitable for public consumption.

Thirdly, there is the need to ensure proper staffing for the quality control units so that the units can be effectively controlled and manned. Given the fact that quality control units exists within the public water agencies, it is necessary that they are well administered so that they can operate at optional capacity. In addition to regular staffing, such staff should be trained and developed so that they can acquire the needed skill. They should be exposed to current practices in quality control so that they can manage effectively the various processes involves in quality maintenance.

Lastly, existing water laboratories in public water agencies ought to be well managed by ensuring regular supply of chemicals and reagents needed for their full operations.

\section{Conclusion}

The study examined the critical issue of quality control in the provision of potable and safe water for public use. Specifically, it determined whether there were significant differences in the way public viewed or rated quality control in the provision of safe and potable water in Oyo State on the basis of some socio-demographic variables such as gender, marital status and socio-economic background.

The study found that there were no significant differences in the way respondents viewed or rated quality control in public water supply. It implied that they all agreed on the need to ensure and promote quality control in the provision of potable water for public consumption. It was recommended that public water agencies should promote and ensure quality control in their production activities as a way of improving their level of service delivery and also safeguard the health of the public on a regular basis.

\section{REFERECES}

Adah, P.D and Abok, G. "Challenges of Urban Water Management in Nigeria: The Way Forward." Journal of Environmental Sciences and Resource Management. 5, no.1 (June 2013): $\quad 111 \quad-\quad 121$. http://www.cenresinpub.org/

Adedayo, A. and Ifabiyi, I. P. "The Distribution of Water and Role of Public Agencies in Kwara State." Journal of Social and Management studies, 5 \& 6, (1999): 97 - 111. 
Ajayi J. O. "Strategy for Effective Administration of Water Resources Development and Management in Nigeria." Journal of Mining and Geology. 42, no.1 (2006): $41-50$.

Ajayi J. O. Sonuga, F. A., Aliboh, O. P. and Oloke, D. A. "Sustainable Potable Water Supply to Nigerians Through Conjuctive Development Surface and Groundwater Resources" in A. A. Elueze (ed) Contributions to Geosciences and Mining to National Development. NMGS Publication, (2003):9 - 17.

Akintola, F. O. and Areola, O. "Patterns and Strategy of Water Supply in Nigeria." Nigerian Journal of Economic and Social Studies, 22, no.1 (1980):41 - 52. www.africabib.org

Akpoborie, I. A. "Implications of Decree 101 for Water Resources Development and Management in Nigeria." Water Resources, 10, (1999): $19-25$.

Akpor, O. B. and Muchie, M. "Challenges in Meeting the MDGs: The Nigerian Drinking Water Supply and Distribution Sector." Journal of Environment Science and Technology, 4, no.5 (2011):480 - 489. http://docsdrive.com/pdfs/ansinet/jest/2011/4 80-489

Areola, O. and Akintola, F. O. "Manpower and Institutional Constraints in Urban Water Supply in Nigeria: A Case Study of the Northwest zone." Geo Journal. 2, no.3 (1979): $125-133$.

Ayoade J. O. "Water Resources and their Development in Nigeria." Hydrological Sciences Bulletin, 20, (1975):581 - 591. www.tandfonline.com/doi/pdf/10.1080

Babatola J. O. "Rural Water Supply: Issues, Problems and Prospects." Water Resources, 8, no.1 (1997):19-25.

Ezeigbo, H. I. "Towards sustainable Potable Water Supply to Nigerians in the New Millennium." In A. A. Elueze (ed) Contributions to Geosciences and Mining to National Development. NMGS Publication, (2003):19 -21 .

Faniran, A. "New Appraoch to Water Supply in Developing Countries: Cases from the
Nigerian Situation." Nature Resources Forum. 7, no.3 (1983):271- 273.

Faniran, A. "Instituttional Arrangement for the Planning and Management of Water Supply in Nigeria." In A. Wunderlia and J. Egberts (eds) Water for the Future: Water Resources Development in Perspective. Rotterdam: A.A. Balkama, (1987):317 - 333.

Faniran, A. "Water Resources Development in Nigeria." University Lecture Series Ibadan: (Ibadan University Press, 1991): 95pp.

Gbadamosi, H. "Fundamentals of Water Supply Technology." Ibadan: Hamid Holdings, (2012):284 - 287.

Goni, I. B. "The Challenges of Meeting Domestic Water Supply in Nigeria.” Journal of Mining and Geology. 42, no.1 (2006):51 - 55. www.ajol.info/index.php/jmg/article/view/18 $\underline{844}$

Hanidu, J. A. "National Growth, Water Resources and Supply Strategies in Nigeria in 1990's." Water Resources. 1, (1990):1-6.

Nwankwoala, H. O. "Sustainable Groundwater Development and Management in Nigeria: Mission Achievable or Mission Impossible?" Water Resources.19, no.2 (2009):63 - 68.

Nwankwoala, H. O. "Improving Water Resources Management in Nigeria: Policy Imperatives and Emerging Realities." Scientia Africana. 10, no.1 (2011):46 - 57. www.scientiaafricana.uniportjournal.info

Nwankwoala, H. O. and Mmom, P. C. "Groundwater UtilazationVersusMillenium Development Goals: Implications for Sustainable Development." Journal of Nigerian Environmental Society (JNES). 4, no.3 (2008):34 - 42 .

Offodile, M. E. "Overview on Sustainable Development and Management of Water Resources in Nigeria." Journal of Mining and Geology, 42, no.1 (2006):57 - 61

Okeke, O. C. and Uzoh, O. F. "Towards achieving Sustainable Water Resources Management in Nigeria." Global Journal of Geological Sciences. 7, no.1 (2009):85 - 92. 
www.cabdirect.org/abstracts/20093088245

Oteze, G. E. "Management Approaches for Nigeria's Water Resources." Journal of Mining and Geology. 42, no.1 (2006):15 20.

www.ajol.info/index.php/jmg/article/view/18 $\underline{840}$

Oyebande, L. "Appropriate Administrative Structures in Harnessing Water Resources for Sustainable Growth in Nigeria. Journal of Mining and Geology, 42, no.1 (2006):21 30.
Rijsbermann, F. R. "Water Scarcity: Fact or Fiction," Agricultural Water Management. 80, (2006):5 - 22.

www.sciencedirect.com/science/journal/0378 $3774 / 80$

Shiklamanov, I. A. "Appraisal and Assessment of the World's Water Resources." Water International. 25, no.1 (2000):11 - 32 . www.tandfonline.com

Tijani, M. N. "The Need for Action-Driven Vision and Sustainable Management of Water Resources in Nigeria." Journal of Mining and Geology. 42, no.1 (2006):31 - 40. 